\title{
Protection of Investors' Rights and the Long-Run Performance of Rule 144A Private Equity Offerings
}

\author{
Seoungpil Ahn (Corresponding author) \\ Sogang Business School, Sogang University \\ PA706, 35 Baekbeom-ro, Mapo-gu, Seoul 121-742, Korea \\ E-mail: spahn@sogang.ac.kr \\ Gwangheon Hong \\ Sogang Business School, Sogang University \\ PA711, 35 Baekbeom-ro, Mapo-gu, Seoul 121-742, Korea \\ E-mail: ghong@sogang.ac.kr
}

Received: Sep. 21, 2016 Accepted: Oct. 31, $2016 \quad$ Published: December 1, 2016

doi:10.5296/ajfa.v8i2.10186 URL: http://dx.doi.org/10.5296/ajfa.v8i2.10186

\begin{abstract}
Equity private placement is the newest method of corporate financing strategy. The private equity financing under SEC Rule 144A is exploding and yet not much is known about the motivation behind private equity placement by public firms. Considering that privately placed firms have no bonding benefit, private equity investors would discount their capital by the amount of expected consumption of private benefits. Therefore, the issuers are unable to lower the cost of capital nor increase managerial perquisites. One possible motivation for private placement then is that firms offering the private DR increase their private benefits with the capital raised subsequently. Our approach is new to literature by incorporating both benefit (conceal private information) and cost (informational monopoly) associated with private equity financing.
\end{abstract}

Keywords: Private Equity Offering, Rule 144A, Cross Listing, Firm Performance, Investor rights, Bonding, Monitoring

JEL: G15, G24, G34 


\section{Introduction}

New capital raising is one of reason why non-US firms listed in the US exchange. Non-US firms can raise equity capital in the US either through public offerings (Levl III ADRs) or through private offerings (Rule 144A). Level III ADRs requires full registration and disclosure of financial statements to SEC and compliance with US GAAP. Rule 144A offerings, however, are exempt from SEC registration and compliance with US GAAP. Accordingly, Rule 144A securities are available only to qualified institutional buyers (QIBs) and can be traded in the PORTAL (Private Offerings, Resale and Trading through Automated Linkages) system.

Since 1990, increasing numbers of foreign companies are raising equity capital in the U.S capital market through Rule 144A private equity placement in the US. Between 1993 and 2002, \$117.1 billion was raised in 557 new public depositary receipt (DR) offerings and \$41 billion was raised in 486 new private depositary receipt (DR) offerings. ${ }^{i}$ The majority of non-US firms in Rule 144A private equity market is from developing countries. In 2002, companies from Taiwan, Mexico, Russia, India, and Korea represent more than $90 \%$ of new private DR program in terms of capital raised and the number of issuance.

Benefits associated with cross-listing, in general, include the reduction of cost of capital and the increase of liquidity in the home market through an enlarged investor base (Foerster and Karolyi, 2000) and reduced information asymmetry with higher disclosure requirement (Hertzel and Smith, 1993). More recently, Reese and Weisbach (2002), and Doidge, Karolyi, and Stultz (2004) argue that a US listing provides bonding and monitoring benefit to cross-listed firms. They argue that the disclosure and accounting compliance requirements for a US exchange listing enhance the protection of the minority shareholders and reduce the agency costs of controlling shareholders.

The bonding and monitoring benefit can be applicable to public exchange listings which require registration and compliance with the US GAAP. However, with its exemption from registration, non-US firms in Rule 144A private market are unlikely to benefit from monitoring from higher investor protection. Because the resales of the securities are restricted to QIBs and privately placed equity is trading at substantial discount, other commonly argued cross-listing benefits such as liquidity effects and the reduction of cost of capital are unlikely to be applicable to Rule 144A private offerings.

We explore the motive for non-US firms to raise equity capital in the US privately. Reese and Weisbach (2002) find that firms from weak investor protection are less likely to cross-list in the public US exchange in afraid of the potential loss of private benefits of control. The private DR program, however, is dominated by firms from countries with weak investor protection. Considering that these firms will not have bonding benefit, private equity investors would discount their capital by the amount of expected consumption of private benefits and the issuers will not lower their cost of capital or increase perquisites. However, it is possible that firms offering the private DR increase their private benefits with the capital raised subsequently. 
Reese and Weisbach (2002) also document the increase in equity issues following cross-listing, specially from issuers from countries with weak investor protection. They conclude that a bonding mechanism provided with the US listing allows firms to raise more capital subsequently. Again, Rule 144A private placement does not require such compliance with SEC regulations and, consequently, non-US firms in Rule 144A will not benefit from bonding and monitoring under the US regulation. It is questionable how non-US firms listed in PORTAL can also raise more capital subsequently.

In emerging markets, the government, oftentimes, guarantee that a firm will not let bankrupt in order to persuade foreign investors to participate in the capital raising. Private DR issuers also might delude home country investors as if their firms receive the same scrutiny as firms listed in the public US exchange such as NYSE and NASDAQ. A listing in formal US exchange can provide prestige and reputation for the non-US firms specially for firms from countries with weak investor protection. If the home country investors are naive, the private equity placement under Rule 144A could give false signal as if the firms achieved the prestige provided by the US public exchange. Once the non-US firms get the "fake" prestige, they can raise capital at lower cost from home capital market and increase private benefits of managers. Some anecdotal evidence illustrates this point: LG Telecom, a South Korea based telecommunication company, issued equity in Rule 144A market in January 2001. Local market newspaper evaluated the issuance as a success as it indicates foreign investors value the future growth opportunities of the company. Though there is a criticism arguing that LG telecom issued the equity at too low price, LG telecom could raise more capital from domestic banks and overseas subsequently.

Foster and Karolyi (2000) find that the long-run stock market performance is lowest for the private DR issuers from lower home market accounting standards, while it is highest for the public DR issuers from lower home market accounting standards. If Rule 144A equity issuance gives domestic investors a false signal about bonding, we expect that more frequent and larger magnitude of capital raising activities after the private DR offering, specially for firms from countries with poor investor protection or undeveloped capital market. We expect that post capital raising activities will be positively related to the discount and negatively related to the amount of capital raised in the private DR issuance. We also expect that the subsequent capital raising activities will be associated with the observed long-term underperformance.

One might argue that private DR offering would be preferred by small, young companies who can not meet the listing requirements of public US exchanges and still want to raise capital in the US quickly and at lower costs. However, considering the deep discount and illiquidity in the private equity market, it is questionable whether the firms can raise capital at lower cost in private DR market than in home capital market. ${ }^{i i}$ The empirical evidence on private DR issuance also suggests that the potential benefits of private DR offerings do not outweigh its costs. Miller (1999) finds negative (but insignificant) short-term abnormal return for private DR offerings. Foster and Karolyi (2000) find that private DR issuers significantly underperform market up to three years after the issuances. 


\section{Previous Literature}

Recent empirical work documents that in countries where legal protections for minority shareholders are weak, it is considerably more difficult for a firm to raise external capital than for a firm in a country that protects minority interest will (La Porta, Lopez, Shleifer, and Vishny 1998, 1999). Reese and Weisbach (2002) and Doidge, Karolyi, and Stultz (2004) argue that the managers under poor investor protection would either expropriate firm's resource at the cost of minority shareholders or pursue growth opportunities by raising capital. Outside investors will not commit their capital unless there is a bonding and monitoring to prevent managers pursuing private benefits. Cross-listing to the US exchange provides such bonding mechanism through higher regulation standards. Reese and Weisbach (2002), and Doidge, Karolyi, and Stultz (2004) argue that the disclosure and accounting compliance requirements for a US listing enhance the protection of the minority shareholders and reduce the agency costs of controlling shareholders. They argue that the benefits of bonding and monitoring through US listing will be higher for firms from poor investor protection. Doidge, Karolyi, and Stultz (2004) argue that the benefits of bonding and monitoring through US listing will be higher for exchange offerings firms than Rule 144A offerings which provides a safe harbor exemption from SEC registration requirement.

Consistently with the argument, Reese and Weisbach (2002) document the increase in equity issues following cross-listing, specially from issuers from countries with weak investor protection. Doidge, Karolyi, and Stultz (2004) find that foreign firms cross-listed in the US are valued higher than the local firms not cross-listed. Rule 144A issuers are also valued more than other local firms, but the listing premium is smaller than exchange (public) issuers. Lins, Strickland, and Zenner (2005) ague that a US listing in the public exchange improves access to capital, specially for firms from emerging market. With higher disclosure and accounting compliance requirement and higher protection on minority shareholders' rights, US exchange listing potentially enhance the protection of the minority shareholders and reduce the agency costs of controlling shareholders. However, Rule 144A private placement does not require such compliance with SEC regulations. Consequently, non-US firms in Rule 144A will not benefit from bonding and monitoring under the US regulation.

\section{Data Description}

Initial sample of Rule 144A offerings is obtained from ADR database in the Bank of New York ADR Division. Between 1991 and 2002, 362 non-US firms raise capital in the US through Rule 144A private equity offerings. We collected stock price data from DataStream. After excluding firms with no data in DataStream, we have 220 non-US firms. From table1, companies from India are the most frequent issuers in Rule 144A equity market followed by Taiwan, Korea, Russia, Mexico, and Turkey. Among the largest issuing countries, DataStream does not cover Russia and Mexico.

We collect country level variables regarding shareholders' legal protection from La Porta, Lopez, Shleifer, and Vishny (LLSV, 1998). LLSV(1998) provides legal origin of the country, index of anti-director rights, and judicial efficiency. English common law countries are viewed, in general, as providing higher investor protection than French civil law and German 


\section{Macrothink}

Asian Journal of Finance \& Accounting

ISSN 1946-052X

2016, Vol. 8, No. 2

countries. Scandinavian civil law countries are in between. Higher index number in anti-director rights and judicial efficiency indicates higher investor protector.

Table 1. Rule 144A Issuance by Countries

\begin{tabular}{|c|c|c|c|c|c|c|}
\hline country & $\begin{array}{c}\text { Initial } \\
\text { Data }\end{array}$ & $\begin{array}{c}\text { DS } \\
\text { Data }\end{array}$ & Legal Origin & $\begin{array}{l}\text { Anti-Direct } \\
\text { or Rights }\end{array}$ & $\begin{array}{c}\text { Judicial } \\
\text { Efficiency }\end{array}$ & $\begin{array}{c}\text { Accounting } \\
\text { Standards }\end{array}$ \\
\hline India & 53 & 39 & English & 5 & 8.00 & 57 \\
\hline Taiwan & 41 & 38 & German & 3 & 6.75 & 65 \\
\hline Korea & 22 & 20 & German & 2 & 6.00 & 62 \\
\hline Russia & 18 & 0 & NA & NA & NA & NA \\
\hline Mexico & 17 & 0 & French & 1 & 6.00 & 60 \\
\hline Turkey & 15 & 12 & French & 2 & 4.00 & 51 \\
\hline Poland & 13 & 6 & NA & NA & NA & NA \\
\hline Egypt & 9 & 5 & NA & NA & NA & NA \\
\hline Italy & 9 & 7 & French & 1 & 6.75 & 62 \\
\hline South Africa & 9 & 9 & English & 5 & 6.00 & 70 \\
\hline Greece & 8 & 6 & French & 2 & 7.00 & 55 \\
\hline Hungary & 8 & 5 & NA & NA & NA & NA \\
\hline Argentina & 7 & 5 & French & 4 & 6.00 & 45 \\
\hline China & 7 & 2 & NA & NA & NA & NA \\
\hline Australia & 6 & 6 & English & 4 & 10.00 & 75 \\
\hline France & 6 & 4 & French & 3 & 8.00 & 69 \\
\hline Philippines & 6 & 6 & French & 3 & 4.75 & 65 \\
\hline Switzerland & 6 & 5 & German & 2 & 10.00 & 68 \\
\hline UK & 6 & 3 & English & 5 & 10.00 & 78 \\
\hline Columbia & 5 & 1 & French & 3 & 7.25 & 50 \\
\hline Japan & 5 & 1 & German & 4 & 10.00 & 65 \\
\hline Germany & 4 & 4 & German & 1 & 9.00 & 62 \\
\hline Peru & 4 & 3 & French & 3 & 6.75 & 38 \\
\hline Portugal & 4 & 3 & French & 3 & 5.50 & 36 \\
\hline Spain & 4 & 1 & French & 4 & 6.25 & 64 \\
\hline Austria & 3 & 3 & German & 2 & 9.50 & 54 \\
\hline Brazil & 3 & 1 & French & 3 & 5.75 & 54 \\
\hline Chile & 3 & 1 & French & 5 & 7.25 & 52 \\
\hline Croatia & 3 & 1 & NA & NA & NA & NA \\
\hline Finland & 3 & 2 & Scandinavian & 3 & 10.00 & 77 \\
\hline Ireland & 3 & 1 & English & 4 & 8.75 & 74 \\
\hline Israel & 3 & 0 & English & 3 & 10.00 & 64 \\
\hline Lebanon & 3 & 1 & NA & NA & NA & NA \\
\hline Netherlands & 3 & 1 & French & 2 & 10.00 & 64 \\
\hline Norway & 3 & 2 & Scandinavian & 4 & 10.00 & 74 \\
\hline Pakistan & 3 & 1 & English & 5 & 5.00 & 61 \\
\hline
\end{tabular}




\section{I Macrothink}

\begin{tabular}{|c|c|c|c|c|c|c|}
\hline Singapore & 3 & 3 & English & 4 & 10.00 & 78 \\
\hline Venezuela & 3 & 3 & French & 1 & 6.50 & 40 \\
\hline Czech Republic & 2 & 2 & NA & NA & NA & NA \\
\hline Estonia & 2 & 0 & NA & NA & NA & NA \\
\hline Indonesia & 2 & 0 & French & 2 & 3.98 & 65 \\
\hline Kazakhstan & 2 & 0 & NA & NA & NA & NA \\
\hline Lithuania & 2 & 0 & NA & NA & NA & NA \\
\hline Luxembourg & 2 & 0 & NA & NA & NA & NA \\
\hline Thailand & 2 & 1 & English & 2 & 3.25 & 64 \\
\hline Denmark & 1 & 0 & Scandinavian & 2 & 10.00 & 62 \\
\hline Ecuador & 1 & 1 & NA & NA & NA & NA \\
\hline Ghana & 1 & 1 & NA & NA & NA & NA \\
\hline Hong Kong & 1 & 1 & English & 5 & 10.00 & 69 \\
\hline Jordan & 1 & 0 & NA & NA & NA & NA \\
\hline Latvia & 1 & 0 & NA & NA & NA & NA \\
\hline Malta & 1 & 0 & NA & NA & NA & NA \\
\hline Morocco & 1 & 1 & NA & NA & NA & NA \\
\hline Nigeria & 1 & 0 & NA & NA & NA & NA \\
\hline Qatar & 1 & 0 & NA & NA & NA & NA \\
\hline Romania & 1 & 0 & NA & NA & NA & NA \\
\hline Slovakia & 1 & 0 & NA & NA & NA & NA \\
\hline Slovenia & 1 & 0 & NA & NA & NA & NA \\
\hline Sri Lanka & 1 & 1 & NA & NA & NA & NA \\
\hline Sweden & 1 & 1 & Scandinavian & 3 & 10.00 & 83 \\
\hline Tunisia & 1 & 0 & NA & NA & NA & NA \\
\hline Virgin Islands & 1 & 0 & NA & NA & NA & NA \\
\hline Total & 362 & 220 & & & & \\
\hline
\end{tabular}

We added index of accounting standards produced by the Center for International Financial Analysis and Research. ${ }^{\text {iii }}$ From table 2, the private DR issuers are dominated by companies from countries with poorer investor protection. There are 89 companies from English common law origin versus, 180 companies from French or German civil law origin. Anti-director rights, judicial efficiency and accounting standards of French and German civil law countries are poor compared with English common law countries. 
Table 2. Legal Origins and Investor Protection

\begin{tabular}{|l|c|c|c|c|c|}
\hline & $\begin{array}{c}\text { Initial } \\
\text { Data }\end{array}$ & $\begin{array}{c}\text { DS } \\
\text { Data }\end{array}$ & $\begin{array}{c}\text { Anti-Director } \\
\text { Rights }\end{array}$ & $\begin{array}{c}\text { Judicial } \\
\text { Efficiency }\end{array}$ & $\begin{array}{c}\text { Accounting } \\
\text { Standards }\end{array}$ \\
\hline English Common Law & 89 & 64 & $\begin{array}{c}4.2 \\
{[4.5]}\end{array}$ & $\begin{array}{c}8.1 \\
{[9.4]}\end{array}$ & $\begin{array}{c}69.0 \\
{[69.5]}\end{array}$ \\
\hline French Civil Law & 99 & 54 & $\begin{array}{c}2.6 \\
{[3.0]}\end{array}$ & $\begin{array}{c}6.4 \\
{[6.4]}\end{array}$ & $\begin{array}{c}54.4 \\
{[54.5]}\end{array}$ \\
\hline German Civil Law & 81 & 71 & $\begin{array}{c}2.3 \\
{[2.0]}\end{array}$ & $\begin{array}{c}8.5 \\
{[9.3]}\end{array}$ & $\begin{array}{c}62.7 \\
{[63.5]}\end{array}$ \\
\hline $\begin{array}{l}\text { Scandinavian Civil } \\
\text { Law }\end{array}$ & 8 & 5 & $\begin{array}{c}3.0 \\
{[3.0]}\end{array}$ & $\begin{array}{c}10.0 \\
{[10.0]}\end{array}$ & $\begin{array}{c}74.0 \\
{[75.5]}\end{array}$ \\
\hline \multicolumn{2}{|c|}{$\mathrm{F}$} \\
{$\left[\chi^{2}\right]$} & & $5.58^{\mathrm{a}}$ & $5.67^{\mathrm{a}}$ & $8.59^{\mathrm{a}}$ \\
{$[11.63]^{\mathrm{a}}$} & {$[12.02]^{\mathrm{a}}$} & {$[14.41]^{\mathrm{a}}$} \\
\hline
\end{tabular}

a: significant at $1 \%$ significance level

\section{Model}

The rational expectation model and signaling can be used in solving this problem. The objective function of firm value maximizing manager includes proprietary costs $(\mathrm{C})$, financing costs $(F)$, monitoring benefits of private financing $(\mathrm{M})$ and the valuation loss from rent seeking activities (R).

$$
\begin{aligned}
& \text { Private equity financing: } E V_{p r}=E\left(V-F_{L}-R(g, I) \mid M(g)\right) \\
& \text { Public equity financing: } E V_{p u}=E\left(V-F_{H}-C(g, c)\right)
\end{aligned}
$$

EVpr and EVpu represent expected value of project from private equity financing and public equity financing, respectively. $\mathrm{V}$ is the revenue from the project. $\mathrm{V}$ is distributed normally with mean $\mu$ and variance $\sigma^{2} . \mathrm{F}_{\mathrm{L}}$ and $\mathrm{F}_{\mathrm{H}}$ are financing costs of private and public equity offering, where $\mathrm{F}_{\mathrm{L}}<\mathrm{F}_{\mathrm{H}}$. The financing costs include discounts due to informational asymmetry and floatation costs (see Besley and Kohers, 2007). C(g,c) is proprietary costs associated with public equity financing (see Dye, 1985, 1998), which is increasing function of the project quality, $\mathrm{g}$, and industry competition, c. Intuition is that, the higher the project quality, the more to lose if the firm's private information is disclosed to its competitors. $M(g)$ is monitoring benefits from private equity financing, which is decreasing function of $g$. $R(g)$ is the rents demanded by inside financiers. The information monopoly of inside financiers gives them the proprietary rights to extract rents. $\mathrm{R}(\mathrm{g})$ is increasing function of the project profitability and decreasing function of the information advantage over outsider investors, I.

The main result we want to prove is as followings. For a given level of $\mathrm{c}$ and I, there will be unique level of project quality, $\mathrm{g}^{*}$, above which private equity financing is strictly preferred, and below which public equity financing is strictly dominant. As the project quality $(\mathrm{g})$ increases, the sum of the benefits from concealing private information and monitoring increases faster than the cost of rent by inside financiers. The cost of rent by inside financiers is 
bounded not only by I, but also by the sum of the benefits from concealing private information and monitoring. Industry competition has an important role in determining inter-industry patterns of private versus public equity financing.

\section{Proposal for empirical tests}

For further analysis, we can test the price run-up before the private DR issuance, announcement return, and long-term performance in the post-issue period. Additional tests include the post-listing capital raising activities and the change in investment rate around listing. If the US capital raising relaxes financial constraints, we expect that the private DR issuers raise more capital subsequently and invest more. If the raised capital flows into positive NPV projects and do not increase private benefits, we expect the increase in investment will be positively related with long-term abnormal return.

However, if the private DR issuance increases managers' private benefits, we can expect negative relationship between post-issuance capital raising activities or capital expenditure and long-term performance. We can also directly measure the change in private benefits as in Benos and Weisbach (2004).

Private equity financing is preferred over public equity offering in the following reasons. First, the flotation costs are much lower in the private equity offering than in public equity offering. Second, if the information asymmetry between manager and private equity buyers is less than that between manager and other outside investors, private equity is less discounted. Third, the private equity financiers exert monitoring on the operational and organizational decisions and thus increases the monitoring efficiency. Fourth, as Verrecchia (1990) argues, when a manager has discretion in disclosing information or withholding information in the presence of traders who have rational expectations about his motivation, the threshold level of disclosure is determined by exogenous proprietary costs. For a firm operating in highly competitive industry and having high growth opportunities may prefer private equity financing to conceal its private information (Darrough, 1993).

However, the private equity financing is not always preferred because of the hold-up problem of private equity financing. Because information asymmetry is much higher for the outside investors, the hold-up problem gives the inside financiers bargaining power over the firm's profits. This valuation loss associated with hold-up problem represents sever discounts in the private equity financing. In conclusion, the private versus public equity offering decision would be determined by the trades off between benefits and costs associated with private equity offering.

\section{Conclusion and implication}

The results are crucially dependent on the form of each cost/benefit functions because we assume that proprietary costs $(\mathrm{C})$, monitoring benefits of private financing $(\mathrm{M})$ and the valuation loss from rent seeking activities $(\mathrm{R})$ are all functions of the project quality, $\mathrm{g}$. We assume that the revenue from the project $(\mathrm{V})$ is normally distributed, but it will be much easier when discrete distribution is assumed. Although we can solve the problem by assuming the first differentiation of $\mathrm{C}(\mathrm{g})$ and $\mathrm{F}(\mathrm{g})$ is $\mathrm{C}^{\prime}(\mathrm{g})>\mathrm{R}^{\prime}(\mathrm{g})$, still it may be hard to define each function 
with proper rationale. In addition, we need to specify the distribution of information advantage which determines the upper-bound of rents. The informational advantage of the inside financiers occurred because they receive less noisy signal about the project value than outside investors do.

This paper is meaningful and interesting in that (1) recently, the private equity financing under SEC Rule 144A is exploding and not much is known about the motivation for private equity financing by a publicly traded firm; (2) our approach is new to literature by incorporating both benefit (conceal private information) and cost (informational monopoly) associated with private equity financing.

\section{References}

Besley, S., \& N. Kohers (2007). Reactions of issuers and rivals to private placements of common equity. Applied Financial Economics, 17, 559-568. http://dx.doi.org/10.1080/09603100600706741.

Benos, E., \& M. Weisbach (2004). Private benefits and cross-listings in the United States. Emerging Market Review, 5, 217-240. http://dx.doi.org/10.1016/j.ememar.2004.01.002.

Doidge, C., A. Karolyi, \& R. Stulz (2004). Why are foreign firms listed in the U.S. worth more?. Journal of Financial Economics, 70, 205-238. http://dx.doi.org/10.1016/S0304-405X(03)00183-1.

Dye, R. (1985). Disclosure of nonproprietary information. Journal of Accounting Research, 23, 123-145. http://dx.doi.org/ 10.2307/2490910.

Dye, R., (1998). Discussion of on the frequency, quality and informational role of mandatory financial reports. Journal of Accounting Research, 36, 149-160. http://dx.doi.org/ $10.2307 / 2491311$.

Foerster, S., \& A. Karolyi (2000). The long-run performance of global equity offerings. Journal of Financial and Quantitative Analysis, 35, 499-528. http://dx.doi.org/ $10.2307 / 2676253$.

Hertzel, M., \& R. Smith (1993). Market Discounts and Shareholder Gains for Placing Equity Privately. Journal of Finance, 58, 459-485. http://dx.doi.org/ 10.2307/2328908.

Kaplan, S., \& P. Strömberg (2002). Financial contracting theory meets the real world: An empirical analysis of venture capital contracts. Review of Economic Studies, 70, 281-315. http://dx.doi.org/10.1111/1467-937X.00245.

La Porta, R., F. Lopez-de-Silanes, A. Shleifer, \& R. Vishny (1998). Law and finance, Journal of Political Economy, 106, 1113-1155. http://dx.doi.org/10.1257/jel.47.4.1076.

Lins, K., D. Strickland, \& M. Zenner (2005). Do non-U.S. firms issue equity on U.S. stock exchanges to relax financial constraints?. Journal of Financial and Quantitative Analysis, 40, 109-133. http://dx.doi.org/10.1017/s0022109000001769. 


\section{Macrothink}

Asian Journal of Finance \& Accounting

ISSN 1946-052X 2016, Vol. 8, No. 2

Miller, D. (1999). The market reaction to international cross-listings: Evidence from Depository receipts, Journal of Financial Economics, 51, 103-123. http://dx.doi.org/10.1016/s0304-405x(98)00045-2.

Reese, W., \& M. Weisbach (2002). Protection of minority shareholder interests, cross-listings in the United States, and subsequent equity offerings. Journal of Financial Economics, 66, 65-104. http://dx.doi.org/ 10.1016/S0304-405X(02)00151-4

Verrechia, R. (1990). Information quality and discretionary disclosure. Journal of Accounting and Economic, 12, 365-380. http://dx.doi.org/10.1016/0165-4101(90)90021-U

\footnotetext{
i Bank of New York's “Depositary Receipts: 2002 Year-End Market Review”

ii Securities in US private equity market (excluding Rule 144A private equity market) are usually traded in deep discount of about $40 \%$ in the US. However, the announcement reaction is on average positive in the stock market. The deep discount associated with the positive announcement return is views as the private issuance has good investment opportunities to overcome the effect of discount.

iii Chapter 1, Volume 1 of International Accounting and Auditing Trends ( $2^{\text {nd }}$ edition 1991), Center for International Financial Analysis and Research, Princeton, New Jersey.
} 